$\underline{\beta}=$

\title{
Comparative studies on the effects of lincomycin and bacitracin on hematobiochemical and immunological parameters in broiler chickens
}

\author{
Ashraf A. Elkomy ${ }^{1}$, Enas Farag ${ }^{2}$, Elshahat I. Elgharbawy ${ }^{2}$, Mohamed Elbadawy ${ }^{1}$ * \\ ${ }^{1}$ Department of Pharmacology, Faculty of Veterinary Medicine, Benha University, 13736, Moshtohor, Toukh, Elqaliobiya, Egypt \\ ${ }^{2}$ Pharmacology Department, Animal Health Research Institute (Benha branch), Benha Egypt. \\ *Corresponding author E-mail: mohamed.elbadawy@fvtm.bu.edu.eg
}

\begin{abstract}
A total of 100 one-day-old healthy broiler chicks were used to study the effects of lincomycin and bacitracin on some hematobiochemical and immunological parameters. Chicks were divided into four equal groups, 25 each. The first group was kept as control; the 2nd group was received $0.5 \mathrm{~g}$ of lincomycin per liter; the $3 \mathrm{rd}$ group was received $100 \mathrm{mg}$ bacitracin per liter and the 4th group was administered both lincomycin and bacitracin, each at the above-mentioned dose. Drugs were given in drinking water for 5 successive days from 20 th to 25 th day of age. Bodyweight was recorded at the beginning of the experiment and at 1st-day post administration where body performance was recorded. One day post administration, blood samples were collected for estimation of hematobiochemical and immunological alterations. The obtained results revealed that broiler chicks administered lincomycin or bacitracin or both revealed a marked increase in bodyweight, weight gain, phagocytic activity, phagocytic index, erythrocytic count, hemoglobin level, packed cell volume, total leukocytic count, serum total protein, albumin, total globulin, $\alpha, \beta$ and $\gamma$ globulin. Furthermore, a significant elevation in malondialdehyde associated with a marked reduction in albumin-globulin ratio, serum total lipid, cholesterol and triglyceride and a significant decrease in catalase and superoxide dismutase, were recorded, compared with the control group. In conclusion, lincomycin and bacitracin either alone or in combination have positive impacts on growth performance, immunological and hematobiochemical parameters of broiler chickens. So, it is recommended to use both drugs as growth promoters in broiler chickens.
\end{abstract}

Keywords: Bacitracin; Biochemical; Chickens; Hematological; Immunological; Lincomycin.

\section{Introduction}

Poultry is considered as a good source of animal protein with a high biological value for human consumption all over the world (Gilmour et al. 2004). Intensive broilers production now exceeds $2 \times 10^{10}$ bird worldwide, but it attracts accusations of poor welfare (Dawkins et al. 2004). Prevention of diseases is the main issue in the poultry industry, due to resulting reduced growth rate and enhanced mortality (Porter 1998, Elbadawy \& Aboubakr 2017). Antibiotic growth promoters have been used for decades in poultry farms as a tool to maintain bird health and improve growth performance (Huyghebaert et al. 2011). Among the well-developed antibiotics that seem promising in veterinary use are lincomycin and bacitracin (Chan et al. 2015). Lincomycin is a naturally occurring lincosamide antibiotic obtained as a fermentation product of Streptomyces lincolnensis. It has a spectrum of activity against Gram-positive bacteria and most anaerobes (Greenwood 2010). Lincomycin acts by inhibition of protein synthesis of bacterial cells (Ali et al. 2014). Several studies have shown lincomycin at low concentrations of 2.2 to $4.4 \mathrm{mg} / \mathrm{kg}$ to be effective in improving weight gain and efficiency of food utilization (Stutz \& Lawton 1984, Dafwang et al. 1987). Bacitracin is a mixture of high molecular weight polypeptides that possess antimicrobial activity against gram-positive microorganisms interfering with the formation of the bacterial cell wall (Butaye et al., 2003). Bacitracin is one of the most extensively used growth promoters to enhance productivity in poultry (Huyghebaert et al., 2011). Studies have reported changes in the gut bacterial flora of broiler chickens associated with dietary supplementation with bacitracin (Lu et al. 2008, Torok et al. 2011). Additionally, bacitracin is used for the treatment and control of many infections in broiler chickens as Clostridium perfringens infection (Rukmini et al. 2015) which is one of the most economically important gut diseases in broiler chickens with a high mortality rate (Aboubakr \& Elbadawy 2017). Few data are available about the effects of both drugs on the healthy broiler chickens. Therefore, the present study was conducted using a large number of chickens to determine the effects of lincomycin and bacitracin on some hematobiochemical and immunological parameters in healthy broiler chickens.

\section{Material and methods}

\subsection{Drugs}


Lincomycin hydrochloride and bacitracin methylene disalicylate were obtained from ATCO pharma for pharmaceutical industries, Cairo, Egypt under the commercial name of ATO LINC $400^{\circledR}$ and BACITOP ${ }^{\circledR}$, respectively. Each gram powder of ATO LINC $400^{\circledR}$ contains $453.6 \mathrm{mg}$ lincomycin $\mathrm{Hcl}$ (eq. to $400 \mathrm{mg}$ lincomycin base). In chickens and turkeys, it is administered orally at a dose of $0.5 \mathrm{gm} / \mathrm{liter}$ drinking water to combat necrotic enteritis (Clostridia spp.), mycoplasmosis and air sacculitis (Mycoplasma gallisepticum), infectious synovitis (Mycoplasma synoviae) and infectious sinusitis (Mycoplasma meleagridis). Each gram powder of BACITOP ${ }^{\circledR}$ contains 62 mg bacitracin methylene disalicylate (eq. to $44.06 \mathrm{mg}$ bacitracin base). It is administered orally at a dose of $100 \mathrm{mg} / \mathrm{liter}$ drinking water for 5-7 days for treatment of Clostridium perfringens infection in broiler chickens.

\subsection{Experimental chickens}

A total of 100, one-day-old Hubbard mixed breed broiler chicks were obtained from a local poultry farm and used in this trial. Birds were kept in wire floor batteries under hygienic measures. All chicks were vaccinated with Newcastle vaccines (HitchnerB1 at 7 days and Lasota at 18 days) and Gumboro vaccine at 14 days. The chickens were maintained at a suitable temperature and humidity according to their ages. The chickens had free access to water and feed. The feed was free from antibacterial drugs. The experiments were performed in accordance with the guidelines set by the Ethical Committee of Faculty of Veterinary Medicine, Benha University, Egypt.

\subsection{Experimental design}

At the $15^{\text {th }}$ day of age, all chickens were randomly divided into 4 equal groups, each of 25 chicks and were allowed to acclimatize for 5 days before administration of drugs. The first group was kept as control; the second one has received lincomycin at $0.5 \mathrm{~g} / \mathrm{L}$. The third group was administered bacitracin at a dose level of $100 \mathrm{mg} / \mathrm{L}$ while the fourth group was given lincomycin and bacitracin together. Administration of drugs was in drinking water for 5 successive days from $20^{\text {th }}$ day of age to $25^{\text {th }}$ day of age.

\subsection{Blood sampling}

Twenty four $\mathrm{h}$ after last administration, two blood samples from each bird were collected, one sample with EDTA as anticoagulant for estimation of hematological parameters (erythrocytic count, packed cell volume, hemoglobin content), total leucocytic count (Weiss \& Wardrop 2010), phagocytic activity (Thompson 1977, Lee \& Bacon 1983) and phagocytic index. The another sample was used for the measuring of serum total protein (Doumas et al. 1981), protein fractions using cellulose acetate electrophoresis test (Henry et al. 1974), total lipid (Frings \& Dunn, 1970), cholesterol (White et al. 1970), triglyceride (Bergmeyer, 1974), superoxide dismutase (Nishikimi et al. 1972), catalase (Sinha 1972) and malondialdehyde (Nielsen et al. 1997).

\subsection{Statistical analysis}

The obtained data were statistically analyzed according to (Petrie \& Watson 2013).

\section{Results}

Healthy broiler chickens received bacitracin and lincomycin either alone or together showed non-significant elevation on body weight and weight gain but improved feed conversion rate throughout the experimental period when compared with the control group (Table 1). It was noticed that use of bacitracin or lincomycin in healthy broiler chickens for 5 successive days results in a marked but nonsignificant increase in erythrocytic count, hemoglobin and packed cell volume, leukocytic count phagocytic activity, and phagocytic index (Table 2). Furthermore, chickens administered bacitracin and lincomycin either alone or together displayed a nonsignificant increase in serum total protein, albumin, total, $\gamma, \beta$ and $\alpha$ globulin coupled with a nonsignificant decrease in albumin globulin ratio at 24 $\mathrm{h}$ after last administration (Table 3). Moreover, oral giving of bacitracin or lincomycin in the tested doses displayed nonsignificant reductions in serum total lipid, cholesterol and triglyceride in healthy broiler chickens when compared with control broilers (Table 4). Furthermore, the obtained results revealed that broilers received lincomycin and/or bacitracin at the tested doses either alone or together showed a significant reduction in catalase and superoxide dismutase (SOD) associated with an elevation in malondialdehyde (MDA) when compared with control broiler chickens (Table 4).

Table 1: Effect of Lincomycin $(0.5 \mathrm{~g} / \mathrm{L})$ and Bacitracin $(100 \mathrm{mg} / \mathrm{L})$ in Drinking Water for 5 Successive Days on Body Performance in Healthy Chickens at the $15^{\text {th }}$ Day of Age and $1^{\text {st- }}$ and $10^{\text {th }}$-Day Post Administration. Values are Mean $\pm \mathrm{SE}(\mathrm{N}=5)$

\begin{tabular}{|c|c|c|c|c|c|c|c|c|c|c|}
\hline \multirow[t]{2}{*}{ Group } & \multirow[t]{2}{*}{$\begin{array}{l}\text { Weight }\left(1^{\text {st }}\right. \\
\text { day of age })\end{array}$} & \multicolumn{3}{|c|}{$15^{\text {th }}$ day of age } & \multicolumn{3}{|c|}{$\begin{array}{c}1^{\text {st- }} \text { day post-treatment }\left(26^{\text {th }} \text { day of }\right. \\
\text { age })\end{array}$} & \multicolumn{3}{|c|}{$\begin{array}{c}10^{\text {th }} \text {-day post-treatment }\left(36^{\text {th }} \text { day of }\right. \\
\text { age })\end{array}$} \\
\hline & & $\begin{array}{l}\text { Bodyweight } \\
(\mathrm{g})\end{array}$ & $\begin{array}{c}\text { Weight } \\
\text { gain }\end{array}$ & FCR & $\begin{array}{l}\text { Bodyweight } \\
(\mathrm{g})\end{array}$ & $\begin{array}{c}\text { Weight } \\
\text { gain }\end{array}$ & FCR & $\begin{array}{l}\text { Bodyweight } \\
(\mathrm{g})\end{array}$ & $\begin{array}{l}\text { Weight } \\
\text { gain }\end{array}$ & FCR \\
\hline Contr & $38.5=$ & $499.6 \pm 9.4$ & $461.1 \pm 13.3$ & 1.2 & $1284.5 \pm 14.6$ & $784.9 \pm 19.4$ & 1.25 & $2079.2 \pm 16.3$ & $794.7 \pm 13.9$ & 1.65 \\
\hline Linco & $38.4 \pm 1.28$ & $498.8 \pm 6$ & \pm 2.9 & 1. & 129 & 79 & 1.2 & & 79 & 1.64 \\
\hline Bacitracin & $38.3 \pm 1.31$ & $498.9 \pm 8.8$ & $460.5 \pm 12.9$ & 1.2 & $1292.7 \pm 16.6$ & $793.7 \pm 14.2$ & 1.24 & $2092.4 \pm 15.6$ & $799.7 \pm 9.9$ & 1.64 \\
\hline $\begin{array}{l}\text { Lincomycin and } \\
\text { bacitracin }\end{array}$ & $38.5 \pm 1.21$ & $502.1 \pm 9.9$ & $463.6 \pm 12.7$ & 1.2 & 14.5 & 796. & 1.23 & 15.7 & $801.1 \pm 8.4$ & 1.64 \\
\hline
\end{tabular}

Table 2: Effect of Lincomycin $(0.5 \mathrm{~g} / \mathrm{L})$ and Bacitracin $(100 \mathrm{mg} / \mathrm{L})$ in Drinking Water for 5 Successive Days on Erythrogram and Leukocytic Count, Phagocytosis and Phagocytic Index in Healthy Chickens, $24 \mathrm{~h}$ after Last Administration. Values are Mean $\pm \mathrm{SE}(\mathrm{N}=5)$

\begin{tabular}{lllllll}
\hline Group & $\mathrm{RBCs}\left(\times 10^{6} / \mu \mathrm{L}\right)$ & $\mathrm{Hb}(\mathrm{gm} / \mathrm{dL})$ & $\mathrm{PCV}(\%)$ & Total WBCs $\left(\times 10^{3} / \mu \mathrm{L}\right)$ & Phagocytosis & Phagocytic index \\
\hline Control & $3.75 \pm 0.33$ & $10.74 \pm 0.93$ & $31.5 \pm 0.84$ & $10.9 \pm 0.33$ & $62.7 \pm 0.54$ & $4.74 \pm 0.38$ \\
Lincomycin & $3.88 \pm 0.49$ & $11.0 \pm 0.87$ & $32.0 \pm 0.75$ & $11.2 \pm 0.21$ & $63.9 \pm 0.98$ & $5.05 \pm 0.79$ \\
$\begin{array}{l}\text { Bacitracin } \\
\begin{array}{l}\text { Lincomycin and bacitra- } \\
\text { cin }\end{array}\end{array}$ & $3.80 \pm 0.28$ & $10.9 \pm 0.72$ & $33.0 \pm 0.68$ & $11.1 \pm 0.23$ & $63.0 \pm 0.84$ & $4.90 \pm 0.81$ \\
\hline
\end{tabular}


Table 3: Effect of Lincomycin $(0.5 \mathrm{~g} / \mathrm{L})$ and Bacitracin $(100 \mathrm{mg} / \mathrm{L})$ in Drinking Water for 5 Successive Days on the Levels of Serum Total Protein (TP), Albumin (Alb.) and Globulin Fraction in Healthy Chickens, $24 \mathrm{~h}$ after Last Administration. Values are Mean $\pm \mathrm{SE}(\mathrm{N}=5)$

\begin{tabular}{|c|c|c|c|c|c|c|c|}
\hline \multirow{2}{*}{ Group } & \multirow{2}{*}{$\mathrm{TP}$} & \multirow{2}{*}{ Alb. } & \multicolumn{4}{|c|}{ Globulin (gm/dL) } & \multirow{2}{*}{$\mathrm{A} / \mathrm{G}$ ratio } \\
\hline & & & $\alpha$ & $\beta$ & $\gamma$ & Total & \\
\hline Control & $5.41 \pm 0.21$ & $3.20 \pm 0.21$ & $0.64 \pm 0.10$ & $0.69 \pm 0.18$ & $0.88 \pm 0.16$ & $2.21 \pm 0.21$ & $1.45 \pm 0.12$ \\
\hline Lincomycin & $5.47 \pm 0.17$ & $3.21 \pm 0.42$ & $0.65 \pm 0.16$ & $0.72 \pm 0.17$ & $0.90 \pm 0.20$ & $2.28 \pm 0.16$ & $1.40 \pm 0.13$ \\
\hline Bacitracin & $5.44 \pm 0.19$ & $3.22 \pm 0.32$ & $0.65 \pm 0.11$ & $0.70 \pm 0.18$ & $0.89 \pm 0.22$ & $2.23 \pm 0.31$ & $1.44 \pm 0.12$ \\
\hline Lincomycin and bacitracin & $5.49 \pm 0.21$ & $3.20 \pm 0.32$ & $0.69 \pm 0.11$ & $0.71 \pm 0.17$ & $0.90 \pm 0.23$ & $2.30 \pm 0.17$ & $1.39 \pm 0.15$ \\
\hline
\end{tabular}

Table 4: Effect of Lincomycin $(0.5 \mathrm{~g} / \mathrm{L})$ and Bacitracin $(100 \mathrm{mg} / \mathrm{L})$ in Drinking Water for 5 Successive Days on Serum Levels of Lipid Profile, Catalase, Superoxide Dismutase (SOD) and Malondialdehyde (MDA) in Healthy Chickens, $24 \mathrm{~h}$ after Last Administration. Values are Mean \pm SE (N=5).

\begin{tabular}{|c|c|c|c|c|c|c|}
\hline \multirow{2}{*}{ Group } & \multicolumn{3}{|c|}{ Lipid profile $(\mathrm{mg} / \mathrm{dL})$} & \multicolumn{2}{|c|}{ Antioxidants enzyme $(\mathrm{U} / \mathrm{mL})$} & \multirow{2}{*}{$\mathrm{MDA}(\mathrm{mmoL} / \mathrm{mL})$} \\
\hline & Total lipid & Cholesterol & Triglyceride & Catalase & SOD & \\
\hline Control & $226.3 \pm 1.87$ & $93.6 \pm 1.94$ & $114.1 \pm 1.82$ & $37.1 \pm 1.40$ & $256.3 \pm 1.49$ & $22.2 \pm 0.39$ \\
\hline Lincomycin & $225.4 \pm 1.78$ & $92.4 \pm 1.74$ & $112.8 \pm 1.86$ & $32.8 \pm 1.01^{*}$ & $250.1 \pm 1.53^{*}$ & $23.9 \pm 0.66^{*}$ \\
\hline Lincomycin and bacitracin & $225.6 \pm 1.84$ & $92.8 \pm 1.69$ & $114.2 \pm 1.82$ & $33.1 \pm 1.10 *$ & $251.1 \pm 1.21 *$ & $23.7 \pm 0.35 *$ \\
\hline
\end{tabular}

$* \mathrm{P}<0.05$.

\section{Discussion}

Healthy broiler chickens received bacitracin and lincomycin either alone or together showed non-significant elevation on bodyweight and weight gain but improved feed conversion rate throughout the experimental period when compared with the control group. The growth promoting the effect of antimicrobials may be due to suppression to the microorganisms that invade the host and retard its metabolic activity (Charleston et al. 1998). Another explanation for improved body performance after using lincomycin and bacitracin is the antimicrobial effect of them which consequently improves the metabolic activity of bird by inhibiting pathogenic organisms that damage gut epithelium and impairing food absorption, inhibiting non pathogenic organisms which compete for growth factors in gut and inhibiting organisms producing toxic substances affecting growth (Abdelaziz 2002). Lincomycin and zinc bacitracin induced an increase in weight gain of broilers (Jiang et al. 2013). The growth promoting the effect of bacitracin might be attributed to a decrease in the thickness of the intestinal wall and thus increases the absorption of nutrients (Henry et al. 1974). Turkeys received zinc bacitracin showed improved body performance (Sims et al. 2004). Our results were agreed with Abaza et al. who mentioned that zinc bacitracin resulted in a progressive significant increase in average final bodyweight, average total weight gain and feed conversion ratio (Abaza et al. 2008). Several other data showed similar results (Ramadan 2017), (Pan et al. 2017, Adel 2018) in broilers received zinc bacitracin. Additionally, lincomycin supplementation to broilers diet significantly improved body weight gain (Sun et al. 2005). Similarly, lincomycin caused in improved weight gain and feed conversion rate in the broilers (Khan and Nagra 2010). Also, the same improvements in body performance were observed in healthy broiler received lincomycin (Mohamed 2016).

Administration of bacitracin or lincomycin or both in healthy broiler chickens for 5 successive days resulted in nonsignificant increases in erythrocytic count, hemoglobin and packed cell volume, leukocytic count phagocytic activity, and phagocytic index. These changes in blood picture may be due to the protection of intestinal epithelium from the toxic effect of subclinical infection of bacteria by tested drugs. It was found that zinc bacitracin in ration induced nonsignificant changes in the total erythrocytic count, hemoglobin, packed cell volume and total leukocytic counts (Ramadan 2017, Adel 2018). Our results were in harmony with those showing that healthy broilers received lincomycin showed nonsignificant increases in the total erythrocytic count, hemoglobin, packed cell volume and leukocytic count (Mohamed 2016). In the same way, healthy broiler chickens received lincomycin showed a significant increase in total erythrocytic count, hemoglobin, packed cell volume and total leukocytic counts (Kadry et al. 2009). Additionally, lincomycin induced a nonsignificant increase in phagocytic activity and index (Fateeva 1983) and (Faden et al. 1985). Furthermore, lincosamides have dramatically increased phagocytic activity (Cialdella et al. 1986) as well as achieves high intracellular levels of phagocytic cells (Alikhani \& Salehifar 2012). Our data coordinated with the findings showing that bacitracin induced a non-significant elevation in phagocytic activity and phagocytic index (Adel 2018).

Our results revealed that chickens are given bacitracin or lincomycin in tested dose each alone or together in drinking water for 5 successive days displayed a nonsignificant increase in serum total protein, albumin, total, $\gamma, \beta$ and $\alpha$ globulin coupled with a nonsignificant decline in albumin globulin ratio at 1st-day post administration. In a similar way, zinc bacitracin induced a non-significant elevation in plasma protein profile levels (Ibrahim 2005, Abaza et al. 2008). Additionally, zinc bacitracin in the diet of broilers chickens was found safe as the liver function tests and protein picture were not altered (El-Bahr et al. 2013). Moreover, bacitracin supplement in ration induced a non-significant elevation in total protein, albumin, total globulin, $\gamma$ globulin, $\beta$ and $\alpha$ globulin (Manafi et al. 2017). Recently, the above-mentioned results were supported by another study that stated that using bacitracin at therapeutic dose induced nonsignificant increase in serum total protein, albumin, total protein, albumin total, $\alpha, \beta$ and $\gamma$ globulin in broiler chickens (Adel 2018). Our results coordinate well with the non-significant alterations in serum total protein, albumin, total, $\alpha, \beta$ and $\gamma$ globulin in healthy chickens received lincomycin (Mohamed 1995, Mohamed 2016) and clindamycin (Ali 2007). Another supporting study stated that growth promoter (bacitracin and lincomycin) induced a non-significant increase in serum total protein, albumin, total, $\alpha, \beta$ and $\gamma$ globulin in healthy broilers (Naveenkumar et al. 2018).

Oral dosing of bacitracin or lincomycin at the tested doses induced a nonsignificant decline in serum total lipid, cholesterol and triglyceride levels in healthy broiler chickens when compared with the control group. The same change in lipid profile after using zinc bacitracin was reported in broiler chicks (Abdulrahim et al. 1996) and in turkeys (Cheng et al. 2002). Other supporting studies (Ibrahim 2005, Li et al. 2006, Teo \& Tan 2007) demonstrated that zinc bacitracin has resulted in a consistent non-significant reduction in plasma total lipid, cholesterol, and triglyceride levels. Similarly, in ducks, zinc bacitracin in diets induced lower in the level of serum total lipid and cholesterol concentration (Wu et al. 2013). Manafi et al. found that bacitracin methylene disalicylate supplement in ration induced the nonsignificant changes in cholesterol, triglyceride (Manafi et al. 2017). Similarly, zinc bacitracin and bacitracin methylene disalicylate induced significant reduction concentrations of serum lipid profiles (Ogboko 2010) and (Chowdhury et al. 2018), respectively. Furthermore, the growth promoters (bacitracin and lincomycin) induced a non-significant reduction in serum total lipid, cholesterol and triglyceride levels in healthy broiler chickens (Naveenkumar et al. 2018).

The obtained results revealed also that, healthy broilers received lincomycin and/or bacitracin either alone or together showed a significant reduction in catalase and superoxide dismutase associated with an elevation in malonaldehyde $24 \mathrm{~h}$ after administration when 
compared with the control group. Consistently with another study, zinc bacitracin has induced a significant decrease in serum superoxide dismutase and catalase while serum malonaldehyde significantly increased (Ding et al. 2011). Also, zinc bacitracin in diets induced a non-significant decrease in activities of superoxide dismutase and catalase in ducks (Wu et al. 2013). Additionally, broilers fed zinc bacitracin in the diet showed a decrease in enzymatic antioxidants (superoxide dismutase and catalase) (El-Bahr et al. 2013). Previous results demonstrated also that, zinc bacitracin in the diet decreased levels of serum enzymatic antioxidants besides increased the lipid peroxidation level (Malondialdehyde) (Ismail et al. 2015). Moreover, zinc bacitracin and bacitracin methylene disalicylate induced a nonsignificant reduction in superoxide dismutase and catalase but malonaldehyde increased (Zhou et al. 2016) and (Chowdhury et al. 2018), respectively.

\section{Conclusion}

Stemmed from our findings, it could be concluded that lincomycin and bacitracin either alone or in combination have positive impacts on growth performance, immunological and hematobiochemical parameters of the broiler chickens. Therefore, lincomycin and bacitracin are a good choice for growth promotion in broiler chickens production.

\section{References}

[1] Abaza IM, Shehata MA, Shoieb MS \& Hassan II (2008). Evaluation of some natural feed additive in growing chicks diets. International Journal of Poultry Science 7, 872-879. https://doi.org/10.3923/ijps.2008.872.879.

[2] Abdelaziz M (2002) Hand Book of Veterinary Pharmacology 5th edn. Faculty of Vet. Medicine, Zagazig University, Zagazig, Egypt

[3] Abdulrahim SM, Haddadin SY, Hashlamoun EA \& Robinson RK (1996). The influence of Lactobacillus acidophilus and bacitracin on layer performance of chickens and cholesterol content of plasma and egg yolk. British poultry science 37, 341-346. https://doi.org/10.1080/00071669608417865.

[4] Aboubakr M \& Elbadawy M (2016). Efficacy of Flagymox ${ }^{\circledR}$ (amoxicillin and metronidazole combination) in controlling Clostridium perfringens Infection in broiler chickens. World Journal of Pharmacy and Pharmaceutical Sciences 6 (1), 80-95. http://www.wjpps.com/wjpps controller/abstract id/6373 \& doi: 10.20959/wjpps20171-8374

[5] Adel AE (2018). Some Pharmacological Studies on Synbiotics and Phytobiotics. Thesis, Department of Pharmacology, Faculty of Veterinary Medicine, Zagazig University, Egypt.

[6] Ali SA, Hasan KA, Bin Asif H \& Abbasi A (2014). Environmental enterococci: I. Prevalence of virulence, antibiotic resistance and species distribution in poultry and its related environment in Karachi. Pakistan Letters in Applied Microbiology 58, 423-432. https://doi.org/10.1111/lam.12208.

[7] Ali SMM (2007). Concurrent Use of Clindamycin with Spectinomycin (Clindaspectin) in Broiler Chicks. Thesis, Department of Pharmacology, Faculty of Veterinary Medicine, Zagazig University, Egypt.

[8] Alikhani A \& Salehifar E (2012). An unreported clindamycin adverse reaction: wrist monoarthritis. Iranian Journal of Pharmaceutical Research 11 (3),959-962. https://www.ncbi.nlm.nih.gov/pubmed/24250524

[9] Bergmeyer H-U (1974). Methods of Enzymatic Analysis V2. 2nd edn. Academic Press,

[10] Butaye P, Devriese LA \& Haesebrouck F (2003). Antimicrobial growth promoters used in animal feed: effects of less well known antibiotics on gram-positive bacteria. Clinical microbiology reviews 16,175-188 https://doi.org/10.1128/CMR.16.2.175-188.2003.

[11] Chan G, Guthrie A, Sivaramalingam T, Wilson J, Vancraeynest D, Moody R \& Clark S (2015). A framework for assessing the efficacy of antimicrobials in the control of necrotic enteritis in broiler chickens. The Journal of Applied Poultry Research 24, 246-256 https://doi.org/10.3382/japr/pfv017.

[12] Charleston B, Gate JJ, Aitken IA, Stephan B \& Froyman R (1998). Comparison of the efficacies of three fluoroquinolone antimicrobial agents, given as continuous or pulsed-water medication, against Escherichia coli infection in chickens. Antimicrobial Agents and Chemotherapy 42, 83-87. https://doi.org/10.1128/AAC.42.1.83.

[13] Cheng HH, Hou WC \& Lu ML (2002). Interactions of lipid metabolism and intestinal physiology with Tremella fuciformis Berk edible mushroom in rats fed a high-cholesterol diet with or without Nebacitin. Journal of agricultural and food chemistry 50, 7438-7443. https://doi.org/10.1021/jf020648q.

[14] Chowdhury S, Mandal GP, Patra AK, Kumar P, Samanta I, Pradhan S \& Samanta AK (2018). Different essential oils in diets of broiler chickens: 2. Gut microbes and morphology, immune response, and some blood profile and antioxidant enzymes. Animal Feed Science and Technology 236, 3947. https://doi.org/10.1016/j.anifeedsci.2017.12.003.

[15] Cialdella JI, Vavra JJ \& Marshall VP (1986). Susceptibility of bacteria to serum lysis or phagocytosis following growth in subinhibitory levels of lincosaminide or spectinomycin related antibiotics. The Journal of antibiotics 39, 978-984. https://doi.org/10.7164/antibiotics.39.978.

[16] Dafwang, II, Cook ME \& Sunde ML (1987). Interaction of dietary antibiotic supplementation and stocking density on broiler chick performance and immune response. British poultry science 28, 47-55. https://doi.org/10.1080/00071668708416935.

[17] Dawkins MS, Donnelly CA \& Jones TA (2004). Chicken welfare is influenced more by housing conditions than by stocking density. Nature, 427, 342-344. https://doi.org/10.1038/nature02226.

[18] Ding YY, Zhang CH, He XL, Huang L \& Yin ZJ (2011). Effects of Chinese herbal medicine additives on antioxidant status, serum biochemical parameters and digestive enzymatic activities in weaned piglets. Journal of Animal and Veterinary Advances 10, $2004-2009$. https://doi.org/10.3923/javaa.2011.2004.2009.

[19] Doumas BT, Bayse DD, Carter RJ, Peters T \& Schaffer R (1981). A candidate reference method for determination of total protein in serum. I. Development and validation. Clinical chemistry 27 (10), 1642-1650. https://www.ncbi.nlm.nih.gov/pubmed/6169466

[20] Elbadawy M \& Aboubakr M (2017). Efficacy of colimox ${ }^{\circledR}$ (a new combination of amoxicillin and colistin) in the control of experimentally induced necrotic enteritis in broiler chickens. International Journal of Pharmacology and Toxicology 5 (1), 51-56. https://www.sciencepubco.com/index.php/IJPT/article/view/7193 \& doi:10.14419/ijpt.v5i1.7193

[21] El-Bahr SM, Ismail IB \& Al-Busadah KA (2013). Oxidative stress biomarkers and biochemical profile in broilers chicken fed zinc bacitracin and ascorbic acid under hot climate. American Journal of Biochemistry and Molecular Biology 3, 202-214. https://doi.org/10.3923/ajbmb.2013.202.214

[22] Faden H, Hong JJ \& Ogra PL (1985). In-vivo effects of clindamycin on neutrophil function. The Journal of antimicrobial chemotherapy 16, 649657. https://doi.org/10.1093/jac/16.5.649.

[23] Fateeva LI (1983). [Lincomycin binding by serum proteins and tissues], Antibiotiki 28, 453-456. https://www.ncbi.nlm.nih.gov/pubmed/6881956

[24] Frings CS \& Dunn RT (1970). A colorimetric method for determination of total serum lipids based on the sulfo-phospho-vanillin reaction. American Journal of Clinical Pathology, 53 (1), 89-91. https://www.ncbi.nlm.nih.gov/pubmed/5410040

[25] Gilmour JT, Koehler MA, Cabrera ML, Szajdak L \& Moore PA Jr (2004). Alum treatment of poultry litter: decomposition and nitrogen dynamics. Journal of environmental quality 33, 402-405. https://www.ncbi.nlm.nih.gov/pubmed/14964397

[26] Greenwood D (2010). Lincosamines. In: Finch R, Greenwood D, Norrby S \& Whitley R (eds) Antibiotic and Chemotherapy: Anti-infective Agents and Their Use in Therapy. Saunders Elsevier, Edinburgh, pp 272-275.

[27] Henry RJ, Winkelman JW \& Cannon DC (1974), Clinical Chemistry: Principles and Techniques. 2nd edn. Happer and Row Publishers, New York, 
[28] Huyghebaert G, Ducatelle R \& Van Immerseel F (2011). An update on alternatives to antimicrobial growth promoters for broilers. The Veterinary Journal 187 (2), 182-188. https://doi.org/10.1016/j.tvjl.2010.03.003.

[29] Ibrahim AEH (2005). Effect of Dietary Zinc Bacitracin on Broiler Chicks Performance and Physiological Responses Under Summer Conditions. Master Thesis, Department of Physiology, Faculty of Veterinary Medicine, University of Khartoum, Khartoum, Sudan.

[30] Ismail IB, Al- Busadah KA \& El- Bahr SM (2015). Biochemical markers of oxidative stress in tissues of broiler chickens fed zinc bacitracin and ascorbic acid under hot climate. International Journal of Biological Chemistry 9, 38-45. https://doi.org/10.3923/ijbc.2015.38.45.

[31] Jiang N, Yang WR, Gao QX, Zhang CY, Liu FX \& Sun XP (2013), Influences of antibiotics on the growth performance and intestinal immunity of Lingnan yellow broilers. Acta Agriculturae Universitatis Jiangx 35 (4), 819-825. http://xuebao.jxau.edu.cn

[32] Kadry MB, Kalil HM, Shawky NA \& Salah A (2009). Evaluation of lincomycin as a therapy of the Clostridium perfringens infection in chickens. Benha Veterinary Medical Journal 20, 1-10.

[33] Khan A \& Nagra SS (2010). Performance of broiler chicks as influenced by feeding diets supplemented with organic acids. Indian Journal of Poultry Science 45, 30-34.

[34] Lee LF \& Bacon LD (1983). Ontogeny and line differences in the mitogenic response of chicken lymphocytes. Poultry science 62, 579-584. https://doi.org/10.3382/ps.0620579.

[35] Li L, Xu CL, Ji C, Ma Q, Hao K, Jin ZY\& Li K (2006). Effects of a dried Bacillus subtilis culture on egg quality. Poultry science 85, 364-368. https://doi.org/10.1093/ps/85.2.364.

[36] Lu J, Hofacre C, Smith F \& Lee MD (2008). Effects of feed additives on the development on the ileal bacterial community of the broiler chicken. Animal: an international journal of animal bioscience 2, 669-676. https://doi.org/10.1017/S1751731108001894.

[37] Manafi M, Khalaji S, Hedayati M \& Pirany N (2017). Efficacy of Bacillus subtilis and bacitracin methylene disalicylate on growth performance, digestibility, blood metabolites, immunity, and intestinal microbiota after intramuscular inoculation with Escherichia coli in broilers. Poultry science 96, 1174-1183. https://doi.org/10.3382/ps/pew347.

[38] Mohamed AGA (2016). Concurrent Uses of Diclazuril and Lincomycin for Controlling of Severe Necrotic Enteritis in Broiler Chicks. Master Thesis, Department of Pharmacology, Faculty of Veterinary Medicine, Zagazig University, Zagazug, Egypt.

[39] Mohamed FAM (1995). Evaluation of Possible Concurrent Use of Both Lincomycin and Spectinomycin in Chickens. Master Thesis, Department of Pharmacology, Faculty of Veterinary Medicine, Zagazig University, Zagazig, Egypt.

[40] Naveenkumar S, Karthikeyan N, Narendra Babu R, Veeramani P, Sivarama Krishnani S \& Srinivasan G (2018). Effect of calcium propionate and coated sodium butyrate as an alternative to antibiotic growth promoters on the serum profile of commercial broiler chicken. International Journal of Chemical Studies 6 (1), 36-39. http://www.chemijournal.com/archives/?year=2018\&vol=6\&issue=1\&ArticleId=1592\&si=false.

[41] Nielsen F, Mikkelsen BB, Nielsen JB, Andersen HR \& Grandjean P (1997). Plasma malondialdehyde as biomarker for oxidative stress: reference interval and effects of life-style factors. Clinical chemistry 43: 1209-1214. http://clinchem.aaccjnls.org/content/43/7/1209.long

[42] Nishikimi M, Appaji N \& Yagi K (1972). The occurrence of superoxide anion in the reaction of reduced phenazine methosulfate and molecular oxygen. Biochemical and Biophysical Research Communications 46, 849-854. https://doi.org/10.1016/S0006-291X(72)80218-3.

[43] Ogboko B (2010). The effect of zinc bacitracin on the physiology of broilers fed plant and animal protein diets. Lucrari stiintifice Seria ZootehnieUniversitatea de Stiinte Agricole si Medicina Veterinara Ion Ionescu de la Brad (Romania).

[44] Pan L, Zhao PF, Ma XK, Shang QH, Xu YT, Long SF, Wu Y, Yuan FM \& Piao XS. (2017). Probiotic supplementation protects weaned pigs against enterotoxigenic Escherichia coli K88 challenge and improves performance similar to antibiotics. Journal of animal science 95 (6), $2627-$ 2639. https://doi.org/10.2527/jas2016.1243.

[45] Porter RE Jr (1998) Bacterial enteritides of poultry. Poultry Science 77, 1159-1165. https://doi.org/10.1093/ps/77.8.1159

[46] Petrie A \& Watson P (2013). Statistics for Veterinary and Animal Science. 3rd edn. Wiley-Blackwell (John Wiley \& Sons, Ltd), United Kingdom.

[47] Ramadan S (2017). Behavior, fear response, performance and immune response of broiler chicks fed graded levels of anise seed as alternative to antibiotics. Alexandria Journal of Veterinary Sciences 55, 74-82. https://doi.org/10.5455/ajvs.276325.

[48] Rukmini M, Sahoo D, Dalei J \& Ray R (2015). Production, purification and characterization of bacitracin from Bacillus subtilis. The Pharma Innovation Journal 3, 77-82. http://www.thepharmajournal.com/vol3Issue12/Issue_feb_2015/3-12-17.1.pdf

[49] Sims MD, Dawson KA, Newman KE, Spring P \& Hoogell DM (2004). Effects of dietary mannan oligosaccharide, bacitracin methylene disalicylate, or both on the live performance and intestinal microbiology of turkeys. Poultry science 83, 1148-1154. https://doi.org/10.1093/ps/83.7.1148.

[50] Sinha AK (1972). Colorimetric assay of catalase. Analytical biochemistry 47, 389-394. https://doi.org/10.1016/0003-2697(72)90132-7.

[51] Stutz MW \& Lawton GC (1984). Effects of diet and antimicrobials on growth, feed efficiency, intestinal Clostridium perfringens, and ileal weight of broiler chicks. Poultry science 63, 2036-2042. https://doi.org/10.3382/ps.0632036.

[52] Sun X, McElroy A, Webb KE, Jr., Sefton AE \& Novak C (2005). Broiler performance and intestinal alterations when fed drug-free diets. Poultry science 84,1294-1302. https://doi.org/10.1093/ps/84.8.1294.

[53] Teo AY \& Tan HM (2007). Evaluation of the performance and intestinal gut microflora of broilers fed on corn-Soy diets supplemented with Bacillus subtilis PB6 (CloSTAT). The Journal of Applied Poultry Research 16, 296-303. https://doi.org/10.1093/japr/16.3.296.

[54] Thompson RA (1977). Technique in Clinical Immunology. Blackwell Scientific Publications, Osney Mead, Oxford OX2 0EL.

[55] Torok VA, Allison GE, Percy NJ, Ophel-Keller K \& Hughes RJ (2011). Influence of antimicrobial feed additives on broiler commensal posthatch gut microbiota development and performance. Applied and environmental microbiology 77, 3380-3390. https://doi.org/10.1128/AEM.02300-10.

[56] Weiss DJ \& Wardrop KJ (2010). Schalm's Veterinary Hematology. 6th edn. Blackwell Publishing Ltd, Philadelphia, U.S.A. https://doi.org/10.1111/j.1939-165X.2011.00324.X

[57] White WL, Erickson MM \& Stevens SC (1970). Determination of cholesterol. In: White WL, Erickson MM, Stevens SC (eds) Chemistry for Medical Technologists. 3rd edn. Saint Louis: C. V. Mosby Co., Saint Louis, USA,

[58] Wu DW, Wang LC, Wen C, Hooge DM, Liang C \& Zhou YM (2013). Effects of replacing a dietary antibacterial agent (zinc bacitracin) with copper salts in Cherry Valley Pekin meat ducks. British poultry science 54, 112-119. https://doi.org/10.1080/00071668.2012.750713.

[59] Zhou M, Wang E, Wang B, Chen Z, Zou Y, Shen S, He B \& Ding H (2016). Substitution of cinnamyl aldehyde for aureomycin and bacitracin zinc in nursery pig diet. Chinese Journal of Animal Nutrition 28 (7), 2106-2112. Doi: 10.3969/j.issn.1006-267x.2016.07.015 